\title{
Ciência Auto-Sustentada: 0 Caso da Esquistossomose
}

\section{Self-Sustained Science: The Case of Schistosomiasis}

\author{
Kurt Kloetzel'
}

KLOETZEL, K. Self-Sustained Science: The Case of Schistosomiasis. Cad. Saúde Públ., Rio de Janeiro, 8 (2): 204-206, abr/jun, 1992.

The author critically reviews the main points of the schistosomiasis control strategies adopted in Brazil during the recent decades, discussing the PECE program and various issues related to chemotherapy, sanitation, and vaccines. The author also discusses the role of public policies in general and, particularly, of scientific policies in the maintenance of the disease in the country.

Keywords: Schistosomiasis; Control; Sanitation; Health Policy; Scientific Policy

Os ingredientes:

Uma endemia bem fornida, uma ciência ensimesmada, voltada para o próprio umbigo, uma variedade de interesses - claros, ocultos e furta-cores.

Deite a mistura em país cálido, com mandatários que alternam entre o pensar complicado e o pensar coisissima nenhuma; ponha em banho-maria e deixe lá! (o produto durará uma eternidade).

A receita adapta-se tal como uma luva à questão da esquistossomose (embora o leitor possivelmente encontre exemplos em sua própria área): por vezes, tem-se a impressão que já foi tombada, incorporada ao patrimônio público, tamanho o carinho que lhe é devotado.

Durante décadas, a solução parecia estar nas mãos dos laboratórios farmacêuticos. Assistiamos, então, ao revezamento de uma legião de drogas esquistossomicidas, todas de fôlego tão curto que não tardavam em passar o bastão ao sucessor. $O$ tratamento medicamentoso estava na ordem do dia e toda uma geração de clínicos empenhava-se na caça aos ovos, com dedicaçāo, esmero e prodigalidade na biópsia retal, tentando demonstrar que a sua eleita acabava com o derradeiro ovo de Schistosoma mansoni.

Mas não vamos exagerar: estas drogas eram realmente eficazes... em pessoas que já se ha-

Departamento de Medicina Social, Faculdade de Medicina, Universidade Federal de Pelotas, Caixa Postal 464, Pelotas, RS, 96010-900, Brasil. viam mudado para o Sul-Maravilha ou de qualquer outra forma rompido com o seu hábitat original. Pois trata-se de um óbvio mais que ululante que a esquistossomose é, por assim dizer, uma doença existencial, uma doença de vivência, cuja solução passa, antes de mais nada, pela mudança de todo um estilo de vida.

Isso não passou despercebido por aqueles que, em 1976-77, elaboravam o Pece (Programa Especial de Controle da Esquistossomose), um grupo de pessoas competentes e bem-intencionadas que não se bastavam com a quimioterapia e queriam juntar-lhe a educação sanitária, o combate ao hospedeiro intermediário, o saneamento básico. Talvez tivesse dado certo, não fosse esse, por parte do governo, mais um jogo de platéia. Decorrida a eleição, assentada a poeira, e estávamos de volta aos vidros de xarope, aos costumeiros comprimidinhos, desta vez por atacado, a nivel de populações inteiras.

Meus próprios estudos de campo, forçadamente interrompidos em 1964, só puderam ser reiniciados em 1982, por instigação da própria Sucam (Superintendência de Campanhas de Saúde Pública do Ministério da Saúde). E aí, ao examinarmos o legado deixado pelo tratamento "em massa" (que, por sinal, prosseguiu aos nossos dias), vimos que, em matéria de transmissão, estávamos de volta à estaca zero, pois que a reinfecção pelo $S$. mansoni era quase que imediata, mesmo as campanhas anuais sendo incapazes de quebrar-lhe o ciclo.

Seria este o momento certo para sentar-se em volta de uma mesa, discutir o que é que dera 
errado, qual a estratégia a ser seguida dai para a frente. Mas a oportunidade foi perdida, parte por inércia, parte por não haver quem vislumbrasse uma alternativa melhor.

Acontece que, a essas alturas, já havíamos aprendido alguma coisa de muito importante, isto é, que nas zonas endêmicas do Nordeste, o grosso da transmissão corre por conta de alguns poucos focos, pequenos e muito bem delimitados: os focos peridomiciliares, já em 1957 antecipados por Pessoa e Pimentel Amorim. Sem poder entrar em detalhes, limitarme-ei a dizer que desenvolvemos alguns métodos de amostragem e rastreamento que permitem uma rápida identificação destes focos, assim dispensando inquéritos dispendiosos.

Isso implica a questão do saneamento básico, sempre encarada como algo de muito utópico. Pois que já não é mais preciso sonhar com faraônicas obras de engenharia sanitária, em escala de macro-ambientes - rios, açudes, lagoas - visto que o maior risco não está nas grandes coleções de água. Um saneamento mais modesto, seletivo, é o que basta, desde que alguém tenha a humildade suficiente para se ocupar de valetas de rua, de poças de fundo de quintal, das privadas do Sesp (Serviço Especial de Saúde Pública do Ministério da Saúde), que, por ocasião da próxima chuva, são vistas a transbordar terreno afora, pois que esqueceram que as fossas de vez em quando têm que ser esvaziadas. (Concordo, trata-se de um trabalho de formiga, muito pouco glamouroso.)

Estou convicto que o controle da esquistossomose está a nosso alcance - $\mathrm{e}$ isso com investimentos modestos. Mediante uma quimioterapia em base seletiva, já por mim recomendada em 1967, associada a medidas de saneamento ambiental igualmente seletivas, acompanhadas de um mínimo de educação sanitária e um máximo de mobilização da comunidade, a tarefa pode ser realizada.

Só há um senão: o marketing para esta proposta é difícil - e não é somente por serem as fossas sépticas e as valetas assuntos que não empolgam a ninguém. $O$ fato é que um programa deste tipo não traz lucros, quer para a indústria, quer para os empreiteiros. Também para o cientista não há atrativos: mesmo no campo das ciências, duvido que o assunto se preste para alguma tese capaz de causar impac- to. (É a maldição que acompanha as coisas simples.)

Mas não seja por isso. Com o desprestígio da quimioterapia, o espaço foi-lhe tomado pela imunologia. Pois, ao contrário da mata amazónica, a ciência é auto-sustentável: mal uma árvore é abatida, logo mais cresce outra em seu lugar, sem deixar clareira. A panacéia agora atende por outro nome - é a vacina contra a esquistossomose que vem para nos acudir. Já há alguns anos monopolizando as verbas para a pesquisa, mantém ocupadas dezenas de laboratórios, milhares de investigadores.

Em outubro do ano passado, no Recife, por ocasião do Terceiro Simpósio Internacional sobre a Esquistossomose, renovei meus contatos com o tema. Admirei as apresentações, vibrei com gráficos e diapositivos, até me dar conta de uma sensação de déjà-vu - alto lá, isso já vi no último carnaval! (Pois que, anos atrás, cada vez que lançavam um novo quimioterápico, era a mesma conversa.)

Por favor, não me entendam mal. Não falo por despeito. Tenho profunda admiração pela pesquisa básica, também já alimentei veleidades deste tipo. Ainda assim, acho que estão delirando, contribuindo para eternizar o S. mansoni: um efeito protetor de $40 \%$ (no camundongo!) não é propriamente animador. Não tenho dúvidas, um dia chegarão aos 60 ou aos $70 \%$, sem que isso deva ser motivo para júbilo. Pois esta vacina custará os olhos da cara, além do que é bem capaz que ela também terá que ser repetida a intervalos curtos. Enquanto isso, com todo este estardalhaço, o saneamento básico - que melhora a qualidade de vida, reduz o risco não só de uma, mas de diversas doenças transmitidas pela água e, da maneira que o propomos, sai bem mais em conta - fica marginalizado.

Tem-se a impressão que a esquistossomose mostrou-se tão útil que não querem acabar com ela. Pois não é só o complexo industrial que corrompe; embora não se dê conta, também o establishment da ciência serve ao mesmo fim. A necessidade interminável de temas para teses, de manter ocupada a dispendiosa parafernália comprada com dinheiro alheio - sem falar na política do "publique ou pereça" - dá à ciência ares de corrida armamentista, quando não de brincadeira inconseqüente. Tão logo um novo campo é desvendado, lá vem ele sendo invadido 
por uma coorte de candidatos a $\mathrm{PhD}$ que, ato contínuo, tratam de plantar sua bandeira na fatia que lhes cabe na Nova Antártica.

Quando chega a esse ponto - à fase da autosustentação - a ciência deixa de ser fator de progresso, passando a servir ao imobilismo, à estagnação.

\section{RESUMO}

KLOETZEL, K. Ciência Auto-Sustentada:

O Caso da Esquistossomose. Cad. Saúde Públ., Rio de Janeiro, 8 (2): 204-206, abr/jun, 1992.

O autor revê criticamente os principais pontos das estratégias de controle da esquistossomose adotadas no Brasil nas últimas décadas, discutindo o programa PECE e questões referentes a quimioterapia, saneamento $\mathrm{e}$ vacinas. $O$ autor também discute o papel das políticas públicas em geral e, em particular, das políticas científicas na manutenção da endemia no país.

Palavras-Chave: Esquistossomose; Controle; Saneamento; Política de Saúde; Política Cientifica 